\title{
The Journal of General Microbiology
}

\author{
Volume 94, Part 1, May 1976
}

\section{DEVELOPMENT AND STRUCTURE}

Isolation and Composition of an Alkali-soluble Glucan from the Cell Walls of Saccharomyces cerevisae. By G. H. Fleet and D. J. ManNers

Some Uttrastructural Features of Micronuclei during Conjugation and Autogamy in Paramecium aurelia. By A. JURAND

The Isolation of Nuclei from the Filamentous Fungus Aspergillus nidulans. By M. A. Gealt, G. SheIRNEISS and N. R. MORRIS

\section{PHYSIOLOGY AND GROWTH}

Accumulation and Storage of $\mathrm{Zn}^{2+}$ by Candida utilis. By M. L. FAILLA, D. C. Benedict and E. D. WeinBERG

Antimicrobial Activities and Antagonists of Bacilysin and Anticapsin. By M. KENIG and E. P. ABrAHAM

The Mode of Action of Bacilysin and Anticapsin and Biochemical Properties of Bacilysin-resistant Mutants. By M. KENIG, E. VANDAMME and E. P. ABRAHAM

Synchronous Growth of Rhodopseudomonas palustris from the Swarmer Phase. By D. WeSTMACoTt and S. B. Primrose

Regulatory Properties of an Inducible Aliphatic Amidase in a Thermophilic Bacillus. By B. Thalenfeld and N. GRossowicz

Phototactic Response of Aerobically Cultivated Rhodospirillus rubrum. By S. HARAYAma and T. IINo

\section{BIOCHEMISTRY}

Identification of $\beta$-Lactamases by Analytical Isoelectric Focusing: Correlation with Bacterial Taxonomy. By M. MATTHEW and A. M. HARRIS

Adenine Nucleotide Pool and Energy Charge During Growth of a Tyrothricin-producing Strain of Bacillus brevis. By G. H. FYNN and J. A. DAVISON

Uptake of Galactose into Escherichia coli by Facilitated Diffusion. By H. L. KorNBERG and C. RIORDAN

Stability of Enzymes in Starving Arthrobacter crystallopoietes. By R. MEGANATHAN and J. C. ENSIGN

Isolation of Lipoteichoic Acids from Butyrivibrio fibrisolvens. By M. J. HEWETT, A. J. WICKEN, K. W. KNOX and M. E. SHARPE

Chloramphenicol Acetylation in Streptomyces. By W. V. SHAw and D. A. Hopwood

Decreased Permeability in a Mechanism of Resistance to Methyl Benzimidazol-2-yl Carbamate (MBC) in Sporobolomyces roseus. By A. NACHMIAS and I. BARASH

Highly Specific Bacteriophage-associated Polysaccharide Hydrolases for Klebsiella aerogenes type 8. By I. W. SUTHERLAND

\section{GENETICS AND MOLECULAR BIOLOGY}

Biochemical and Genetic Characterization of a Carbamyl Phosphate Synthetase Mutant of Escherichia coli K12. By F. Bolivar, M. Galván and J. Martuscelli

\section{MEDICAL MICROBIOLOGY}

Relationship of Structure to Function in Bacterial Endotoxins: Serologically Cross-reactive Components and their Effect on Protection of Mice against some Gram-negative Injections. By A. K. NG, C. H. Chen, C. M. Chang and A. NotwotNY

\section{TAXONOMY}

Peptococcus heliotrinreducans, sp.nov., a Cytochrome-producing Anaerobe which Metabolizes Pyrrolizidine Alkaloids. By $G$. W. Lanigan

A Taxonomic Study of the Aeromonas hydrophila-Aeromonas punctata Group. By M. PopofF and M. Véron

Classification of Micrococci on the Basis of Deoxyribonucleic Acid Homology. By N. OgasawaraFuJiTA and K. SAKAGUCHI

Specificity of Cytoplasmic and Cell-wall Antigens from!Four Species of Phytophthora. By D. M. HaLsall

SHORT COMMUNICATIONS

Chromosomal Location of the $\phi$ C-Prophage in Nocardia erythropolis. By G. H. BrownelL

Effect of Glucose, Ammonium and Media Maintenance on the Time of Condiophore Initiation by Surface Colonies of Aspergillus nidulans. By M. PASTUSHOK and D. E. AXELROD

Arabinose with LL-Diaminopimelic Acid in the Cell Wall of an Aerobic Cornyeform Organism Isolated from Human Skin. By D. G. PITCHER

Agar as a Carbon Source and its Effect on the Utilization of Other Carbon Sources by Acetate Nonutilizing (acu) Mutants of Aspergillus nidulans. By M. PAYTON, W. MCCullough and C. F. ROBERTS

Volumes $92-97$ (1976) $£ 13.00$ (\$42.00 U.S.A. and Canada) each.

Single Parts $£ 8.00$ (\$26.00 U.S.A. and Canada) each.

\section{CAMBRIDGE UNIVERSITY PRESS}

Bentley House, 200 Euston Road, London NW1 2DB

32 East 57th Street, New York, N.Y. 10022 


\section{INDIAN JOURNAL OF DAIRY SCIENCE}

Volume 29 , No. 1

March, 1976

Articles

1. Head space carbonyls in fresh and stored desi ghee by K. L. GABA and M. K. JAIN.

2. Studies on buffalo ghee-Part I Seasonal variation in fatty acid composition and other properties of ghee by C. H. JosHr and S. H. VYAS.

3. Studies on buffalo ghee-Part II Various conditions affecting the granulation of ghee by $C$. $H$. JosH and $S$. H. VYAS.

4. Studies on Provolone cheese - Part I Chemical Composition by M. A. El-SODA, I. S. EL HagarawY, S. E. Rakshy and A. ABOU DONIA.

5. Role of lipolytic bacteria in degradation of fat in experimental cheddar cheese during ripening by AJIT SINGH, R. A. SRINIVASAN and $A . T$. DUDANI.

6. Studies on nutritive value of guara (Cyamopsis tetragonoloba) by KRIPAL SINGH, P.C. Gupta, RaNDHIR SINGH and K. PRADHAN.

7. Effect of formaldehyde treatment on protein protection of groundnut and linseed cakes by A. P. Sinha, N. K. Prasad and A. K. TRIPATHI.

8. Milk production efficiency in Brown Swiss $x$ Sahiwal crossbred and Sahiwal cows by V.S. RanNa, D.S. BhatNagar and M. V. N. Rao.

9. Milking behaviour of Murrah buffaloes by P. C. Dash, S. B. Basu, K. N. S. Sharma and P. A. Sharma.

10. Studies on estimation of body surface area of Indian cattle Part II-Body surface area

from body weight together with a linear measurement by S. N. PANI, S. GuHA and P. BHatTacharya.

11. Prediction of lactation yield from colostrum, peak and 45 days' cumulative yield in dairy cattle by R. S. Chauhan, R. R. Mishra and D. S. BHATNAGAR.

12. Mortality in crossbred calves vis-a-vis Zebu calves by K. N. S. SHarma and D. K. JAIN.

\section{Short communications}

1. Studies on leucocyte counts of buffalo milk by B. R. Malhotra, D. R. Ghodekar and V. K. N. NAMBUDRIPAD.

2. Activity of microbial lipases at low temperature by AJIT Singh, R. A. SRInivasan and A. T. DUDANI.

3. A note on bacteriological quality of market milk in Rewa city by R. G. DwIVEDI.

4. A note on the nutritive value of crop residues green gram (moong) and black gram (urd) by Kripal Singh, P. C. GuPta, RANDhIR Singh and K. Pradhan.

5. Type of udders and teats in relation to milk production and udder health in Sahiwal cows by D. W. KhIRE, V. R. Thatte, M. S. KaDU and P. M. Belorkar.

6. A note on some production and reproduction traits of a Jersey herd at Bassi, Rajasthan by B. S. Malik, Shri Ram and A. L. ChaudHARY.

Price Rs. $40 /-(\$ 10.00$ or $£ 4.00)$ per annum

Published by: Indian Dairy Science Association, IDSA House, Sector IV, R. K. Puram, New Delhi 110 022, INDIA 


\section{DIRECTIONS TO CONTRIBUTORS}

\section{GENERAL}

Two copies of manuscripts should be sent to Dr M. E. Sharpe (The Journal of Dairy Research), National Institute for Research in Dairying, Shinfield, Reading, RG2 9AT, England. Submission of a paper will be held to imply that it reports unpublished original work, that it is not under consideration for publication elsewhere, and that if accepted for the Journal it will not be published elsewhere in any language, without the consent of the Editors.

\section{FORM OF PAPERS}

The author should follow these directions carefully, and consult a current issue of the Journal for guidance on details of typographical and other conventions.

Every paper should be headed with its title, the names and initials of the authors (women supplying one given name) and the name and address of the laboratory where the work was done.

Papers should be in English, using the spelling of the Shorter Oxford English Dictionary. They should be typed with double spacing, on one side only of the sheets, and with ample margins for editorial annotations.

Papers should in general be divided into the following parts in the order indicated: (a) Summary, brief and self-contained; (b) Introductory paragraphs, briefly explaining the object of the work but without giving an extensive account of the literature; (c) Experimental or Methods; $(d)$ Results; (e) Discussion and Conclusions; $(f)$ Acknowledgements without a heading; $(g)$ References. With some types of material headings other than $(c),(d)$ and $(e)$ may be preferable.

The use of footnotes should be avoided if possible. Underlining should be used only to indicate italics. Proper nouns, including trade names, should be given a capital initial letter. Wherever possible numerals should be used unless this leads to ambiguity. The typescript should carry the name and address of the person to whom the proofs are to be sent, and give a shortened version of the paper's title, not exceeding 45 letters and spaces, suitable for a running title in the Journal.

\section{TABLES}

Tables should be numbered and should carry headings describing their content. They should be comprehensible without reference to the text. They should be typed on separate sheets and their approximate positions in the text indicated. To minimize the cost of printing, the number and size of tables should be kept to an absolute minimum.

\section{ILLUSTRATIONS}

Line drawings, which must be originals, should be numbered as Figures and photographs as Plates, in Arabic numerals. Drawings should be in Indian ink, on Bristol board or cartridge paper. However, a technique which may be more convenient to authors is to use a double-sized piece of tracing paper, or translucent graph paper faintly lined in blue or grey, folded down the centre with the drawing on one half and the other half acting as a flyleaf.

Attached to every figure and plate there should be a translucent flyleaf cover on the outside of which should be written legibly: (a) title of paper and name of author; (b) figure or plate number and explanatory legend; (c) the figures and lettering, which are intended to appear on the finished block, in the correct positions relative to the drawing underneath. Each paper should have a separate typed sheet listing figure and plate numbers with their legends, and the approximate positions of illustrations should be indicated in the text.

The photographs and diagrams should be about twice the size of the finished block and not larger overall than the sheets on which the paper itself is typed. For a figure measuring $250 \mathrm{~mm} \times 150 \mathrm{~mm}$ all lines, axes and curves should be $0.4 \mathrm{~mm}$ thick, thus Graph symbols in order of preference are $\bigcirc, \Delta \Delta$, $\square \mathbf{E}, \times+$, and for a $250 \mathrm{~mm} \times 150 \mathrm{~mm}$ graph the circles should be $3 \mathrm{~mm}$ in diam. The triangles should be equilateral of $3 \mathrm{~mm}$ side, and the squares also of $3 \mathrm{~mm}$ side. The crosses should have lines $3 \mathrm{~mm}$ long at right angles. Scale marks on the axes should be on the inner side of each axis and should be $3 \mathrm{~mm}$ long.

\section{SHORT COMMUNICATIONS}

Short communications or notes of not more than 2500 words or the equivalent space in print and without a summary will also be published.

\section{REFERENCES}

In the text, references should be quoted by whichever of the following ways is appropriate: Arnold \& Barnard (1900); Arnold \& Barnard (1900a); Arnold \& Barnard $(1900 a, b)$; (Arnold \& Barnard, 1900). Give all the surnames of 3 authors at the first mention, but in subsequent citations and in all cases where there are more than 3 authors give only the first surname (e.g. Brown et al.) provided that there is no possible ambiguity.

References should be listed alphabetically at the end of the paper. Titles of journals should be given in full, authors' initials should be included, and each reference should be punctuated in the typescript thus: Arnold, T. B., Barnard, R. N. \& Compound, P. J. (1900). Journal of Dairy Research 18,158. References to books should include names of authors, year of publication, title, names of editors, town of publication and name of publisher in that order, thus: Arnold, T. B. (1900). Dairying. London: Brown and Chester.

It is the duty of the author to check all references.

\section{UNITS, SYMBOLS AND ABBREVIATIONS}

SI units must be used, as explained in British Standards Institution publication PD 5686:1972, The use of SI units. Until SI units are widely understood, it is permissible to give the equivalent value in other units in parenthesis. Symbols and abbreviations used are those of British Standard 1991: Part 1: 1967. Letter Symbols, Signs and Abbreviations.

\section{DESCRIPTIONS OF SOLUTIONS}

Normality and molarity should be indicated thus: $\mathrm{N}-\mathrm{HCl}, 0 \cdot 1 \mathrm{M}-\mathrm{NaH}_{2} \mathrm{PO}_{4}$. The term ' $\%$ ' means $\mathrm{g} / 100 \mathrm{~g}$ solution. For $\mathrm{ml} / 100 \mathrm{ml}$ solution the term ' $\%(\mathrm{v} / \mathrm{v})$ ' should be used and for $\mathrm{g} / 100 \mathrm{ml}$ solution the correct abbreviation is ' $\%(\mathrm{w} / \mathrm{v})$ '.

\section{REPRINTS}

Order forms giving quotations for reprints are sent to authors with their proofs. 


\section{Journal of Dairy Research \\ Volume 43, Number 2, June 1976 \\ CONTENTS}

Retirement of DR C. C. THEIL

pages $195-196$

ORIGINAL ARTICLES

Acetate utilization by the isolated perfused guinea-pig mammary gland T. B. MEPHAM, S. R. DAVIS and J. R. HUMPHREYS

Variations in the susceptibility of lactating and non-lactating bovine udders to infection when infused with Escherichia coli A. J. BRAMLEY

Effect of feeding fat to dairy cows receiving a fat-deficient basal diet: I. Milk yield and composition

W. BANKS, J. L. CLAPPERTON, M. E. FERRIE and A. G. WILSON

Effect of feeding fat to dairy cows receiving a fat-deficient basal

diet: II. Fatty acid composition of the milk fat

W. BANKS, J. L. CLAPPERTON and M. E. FERRIE

Carotene and immunoglobulin concentrations in the colostrum and milk of pasture-fed cows

D. F. NEWSTEAD

Autoxidation in milk rich in linoleic acid: II. Modification of the initiation system and control of oxidation

G. S. SIDHU, M. A. BROWN and A. R. JOHNSON

Enzymic methods for estimation of the somatic cell count in

bovine milk: I. Development of assay techniques and a study of their usefulness in evaluating the somatic cell content of milk

B. J. KITCHEN

The quantitative measurement of whey proteins using polyacrylamide-gel electrophoresis

R. M. HILLIER

Heat stability of forewarmed milks; influence of $\kappa$-casein, serum proteins and divalent cations

P. A. MORRISSEY and F. O'MAHONY

Autolysis of Streptococcus cremoris

L. MOU, J. J. SULLIVAN and G. R. JAGO

Cytochemical observations on the extracellular carbohydrate

produced by Streptococcus cremoris

B. E. BROOKER

Amino acid nutrition of some commercial cheese starters in relation to their growth in peptone-supplemented whey media

B. A. LAW, EMEL SEZGIN and M. E. SHARPE

The contribution of starter streptococci to flavour development in

Cheddar cheese

B. A. LAW, M. J. CASTAÑ ÓN and M. E. SHARPE

The production of sulphur compounds in Cheddar cheese and

their significance in flavour development

D. J. MANNING, H. R. CHAPMAN and Z. D. HOSKING

SHORT COMMUNICATIONS

Influence of temperature on the electrical conductivity of buffalo milk

G. S. SHARMA and N. K. ROY

$321-323$

Composition of ewe's milk

A. P. WILLIAMS, D. R. BISHOP, J. E. COCKBURN and K. J. SCOTT

The role of $\alpha$-lactalbumin in the primary phase of chymosin action on heated casein micelles

S. I. SHALABI and J. V. WHEELOCK

Reviews of the progress of Dairy Science: continuous cheese-making N. J. BERRIDGE

(C) Proprietors of The Journal of Dairy Research 1976

Printed in Great Britain at the University Printing House, Cambridge 